\title{
The managerial duties of the nurse in charge of a unit in combating the spreading of HIV/AIDS
}

\author{
D Isaacs, B Cur, Department of Nursing, Rand Afrikaans University \\ K Jooste, D Litt et Phil, Department of Nursing, Rand Afrikaans University
}

\section{Abstract}

The charge sister has an essential role to play in combating the spreading of the HIV in the environment of the nursing unit. The HIV/AIDS dilemma is a reality in the health care environment. On a daily basis nurses is treating patients with the HIV. Through the basic conceptual framework of the management process, the charge sister can play her part and contribute in keeping the disease under control in her work environment. An explorative, descriptive study was done through a structured questionnaire with four open questions. This study was aimed at developing and formulating guidelines to be included in a policy to be used in the combating of spreading of HIV in the health care unit by the charge sister and her staff. The results indicate the absence of policy regarding the prevention of the spreading of the HIV, necessary for orientation and in service training of staff.

\section{Abstrak}

Die suster in bevel speel " $n$ essensiële rol in die bekamping van die verspreiding van die MIVirus in die verpleegeenheidomgewing. Die MIV/Vigs dilemma is a realiteit in die gesondheidsorgomgewing. Op ' $n$ daaglikse basis word pasiënte met die MIVirus deur verpleegkundiges verpleeg. Deur die konsepsuele raamwerk van die bestuursproses, kan die bevelsuster ' $n$ rol speel en bydra tot die beheer van die verspreiding van die siekte in haar werksomgewing. " $n$ Ontdekkende, beskrywende studie is uitgevoer by wyse van ' $n$ gestruktureerde vraelys met vier oop eindigende vrae.Hierdie studie was gemik op die ontwikkeling en formulering van riglyne vir insluiting in " $n$ beleid wat gebruik kan word in die bekamping van die verspreiding van die MIVirus in die gesondheidsorgeenheid deur die bevelsuster en haar personeel. Die bevindinge dui op ' $n$ afwesigheid van beleid ten opsigte van die voorkoming van die verspreiding van die MIV, wat nodig is vir die oriëntering en indiensopleiding van personeel.

\section{Introduction and rationale}

The managerial duties of the charge sister in a nursing care unit involves the managerial functions of planning, organizing, and directing and control in combating HIV/AIDS in the environment of the unit. The role of the charge sister should focus on the prevention of the spreading of the HIV from one person (patient/nurse) to another in the unit. Most health care systems still lack clear guidelines and policies on various aspects of HIV/AIDS care (Nurses day 2003:44). It is important that the charge sister ensures that the HIV/ AIDS patients in the unit are managed without any discrimination towards them and that nursing care focus on the enhancement of the life span. Within a HIV/AIDS scenario the charge sister should ascertain that HIV/AIDS patients are managed in totality, meaning that their physical, social, psychological, spiritual and emotional needs are attended to. Research by Kohl and Miller (1994:47) has indicated that nurse managers are not adequately trained to deal with AIDS in the workplace and that they have not developed policies and procedures to deal with this situation. Ten years later, one should assume this should be in place.

In South Africa there is a HIV/AIDS pandemic whereby most of the human deaths occurring are due to HIV/AIDS. HIV/AIDS is also spreading faster in South Africa than anywhere else in the world. According to South Africa's government, four million of its $\mathbf{4 3}$ million people have HIV and 1,700 more are infected daily. With a total of 4.2 million infected people, South Africa has the largest number of people living with HIV/AIDS in the world, as well as one of the world's fastest-growing epidemics. Already, 1 in 4 South African women between ages 20 and 29 are infected with the virus. The Johannesburg Hospital estimates that 40 percent of men of the ages between 20-29 are HIV-positive. (http://iournalism.berkelev.edu/projects/safrica/adapting/ rape. $h t m l)$

The above highlights the important role of the nurse man- 
ager to combat the spreading of the HIV in the environment of the nursing unit. The researcher noted that in his working environment at a public training hospital in Gauteng, specific policies for addressing the prevention of spreading of HIV in nursing units were absent or unknown to staff members. This study was aimed at developing and formulating guidelines to be included in a policy to be used in the combating of spreading of HIV in the health care unit by the charge sister and her staff.

\section{Conceptual framework}

The conceptual framework of the study is based on the

becomes very affected, the illness progress to AIDS.AIDS stands for Acquired Immune Deficiency Syndrome. There is no cure for AIDS: Prevention is the only way to stem the spread of this deadly virus. ( http://www.infoweb.org/library/misc/misc000040.html)

Planning is the process of determining what should be done, why it should be done, where it should be done, by who it should be done, when it should be done, and how it should be done", (McConnell, 1997:51). Planning should be done with consideration to set policies and procedures. Policy making is essential in managing a unit effectively. Policy is written guidelines that regulate the execution of specific responsibilities in the unit. Policy should direct the charge sister" $s$ functions in the prevention of HIV/AIDS in the health care unit. Presently there is no guideline to be used by the charge sister in the unit on management of HIV/AIDS in the hospital unit

According to Muller (1998:133), organization in the nursing unit refers to the orderly structuring of func-

four main steps of the management process. In discussion of the framework the key concepts of the study are also described.

The management process consists of planning, organizing, directing and control. It is the role of the charge sister/ professional nurse to manage the prevention of the spreading of HIV/AIDS in the health care unit, that could occur among patients and/or nursing staff members. The term patient refers to any person who is not healthy and required medical attention. For the purpose of the study the patient was viewed in a medical or surgical nursing care unit with nursing needs that had to be met by nursing care personnel. For the purpose of this study the term professional nurse or charge sister referred to the charge and deputy charge sisters working in the medical and surgical wards of a public training hospital.

The term HIV refers to human immunodeficiency virus. The HIV affects the immune system. The immune system is the body's defence against infections by micro-organism (such as very small bacteria or viruses) that get past the skin and mucous membrane and cause disease. The immune system produces special cells called antibodies to fight or kill these micro organisms. A special weakness of the immune system is called immunodeficiency. When the immune system tions or responsibilities in order to ensure the smooth running of activities. It requires job division by way of an organizational, the demarcation of authority in the form of line and staff functions, as well as the delegation of duties, tasks and responsibilities to the appropriate members. $D i$ recting refers to the unit manager's leadership responsibility, namely to give direction and ensure that goals are achieved in the unit (Jooste, 2001:146). Directing is also a facilitating function in which the unit manager practices applicable leadership in undertaking, motivation and empowerment of group members or subordinates in the nursing unit. Directing is, therefore an enabling management activity, which is aimed at the achievement of the objectives of the nursing unit. The unit manager should also facilitate harmony in the nursing unit and focus on the principles of teamwork and how to deal with conflict in the health care unit (Muller, 1998:134).

Generally, the prevention of the spreading of HIV in the health care unit may be achieved by the use of the correct managerial skills and the quality of the resources available to be utilized in the unit. The charge sister should be able to organize the day-to-day activities effectively in the unit. Charge sister should also be knowledgeable with regards to the management of HIV/AIDS. (McConnell, 1997:52)

Controlling means developing performance standards, 
establishing report systems, monitoring employees' activities to determine whether the organization is on target towards its goal and to make adjustments to encourage outcomes to conform with expected results (Daft, 1999:35). It could be viewed as the empowerment of subordinates or group members to achieve set objectives successfully. The unit manager's controlling function can be divided into proactive, continuous and reactive control. Proactive control refers to the measures, which are introduced to ensure that things run smoothly in the unit. Continuous control refers to supervising and directing in the unit supervising and directing which focus on the empowerment of personnel in the unit to provide quality nursing care (McConnell, 1997:52)

The charge sister should use all her managerial functions to prevent the spreading of HIV among staff and patients in the health care unit.

\section{Problem statement}

Within the health care units of a public training hospital it was observed that the different categories of nurses seemed not to pay serious attention to the prevention of the spreading of HIV/AIDS amongst and between patients and nurses in the nursing care unit. For the researcher it seemed that nurses were not focusing on treating all their patients as potential candidates with HIV/AIDS. The absence of guidelines on the prevention of the spreading of HIV in the health care unit that should be utilized by nursing staff is a serious concern. The absence of guidelines could further complicate the issue of spreading the HIV to nursing staff. When one focus on the prevention of spread of HIV/AIDS in the health care unit the charge sister should consider the consequences of the disease for the health care personnel, the patient as well as their family and their love ones in the community. HIV/AIDS is becoming a pandemic disease; therefore proper guidelines on the management of HIV/ AIDS should be formulated.

The problem statement was formulated through the following question:

"What are the management duties of a charge sister in combating the spreading of the HIV in a nursing care unit?"

\section{Research questions}

From the problem statement the following research questions were formulated for this study:

a) How should the charge sister plan to combat the spreading of the HIV in the health care unit?

b) How should the charge sister organize the daily nursing activities in the unit to prevent the spreading of the HIV in the health care unit?

c) In which ways should the sister direct the nursing staff to effectively prevent the spreading of the HIV in the unit environment?

d) On which control measures should the charge sister focus to combat the spreading of the HIV in the health care unit?

\section{Purpose of the research study}

The main purpose of this study was to:

Explore and describe the important managerial duties of the charge sister in the prevention of the spreading of HIV in the nursing care unit; to formulate guidelines to lead to policy statements on combating the spreading of the HIV within a nursing unit. This contribution could direct future nursing activities in the nursing care unit and could be addressed during in-service training sessions, in educating all the nursing staff members on the evidence of the findings.

\section{Research design}

An explorative and descriptive research design (Holloway and Wheeler, 1996: 3-9) was used to gain data regarding the managerial duties of charge sisters with regards to prevention of spreading of HIV/AIDS in the health.

\section{Explorative}

This research study was an explorative in nature with the aim of gaining knowledge of the managerial duties of charge sister with regards to the prevention of HIV/AIDS in the health care unit.

\section{Descriptive}

Descriptive studies are used to collect accurate data on specific domain phenomenon, which in this study will focus on the dilemma of the spreading of HIV. The researcher will accurately and carefully describe guidelines after collected data has been analysed (Brink, 2001:10-10)

\section{Research method}

A survey method was used.

\section{Population and sampling}

The nurse in charge and the nurse second in charge of all medical and surgical units at a public training hospital in Johannesburg were identified as the population for the study. The total population for the research was 20 professional nurses, who complied with the criteria of being allocated in charge or second in charge in the five medical and surgical units of the public hospital.

Purposive, convenient sampling was used. According to Woods and Catanzano (1988:101) a convenient purposive sample is done to obtain the required data from the sample which possess the same characteristics to be studied and was the representative of the population of the interest. The population served as the sample. All the participants were registered with the SANC as professional nurses, allocated in a similar job position and were females.

\section{Data Collection Method}

Four open-ended questions (see four research questions) were put to the participants in a questionnaire format. These 
questions address the planning, organizing, directing and controlling functions of the professional nurse as charge sister in preventing the spreading of the HIV among staff and patients in the health care units.

\section{Data analysis}

Coding was used to organize data collected in the open questions. Manual activities were used to develop categories of the themes and involved a thorough review of all recorded information that the researcher has obtained during the course of data collection. The data of the participants was constantly compared in the determination of the final main guidelines for prevention of spreading of the HIV (Brink, 2001:192 - 193). The data was analysed according to the method and steps suggested by Tesch (1990 in Creswell, 1994:154-155) and an independent coder coded the data as a measure to ensure reliability or dependability. The following steps was used in analysing the data obtained:

- $\quad$ coding for themes;

- categorizing;

- making notes about the context and variations in the phenomenon under the study;

verifying the selected themes through reflection on the data and discussion with my supervisor in the field.

\section{Trustworthiness}

Accurate analysis of the collected data was performed using the steps outlined above under point 1.9.3. The supervisor verified the selected themes and coding. The subject literature was utilized to confirm the trustworthiness of the of the data analysis.

Lincoln and Guba's model (in Babbie and Mouton 2001:276278) was utilized to ensure trustworthiness in this research. Trustworthiness was ensured according to the four principles related to credibility, transferability, dependability and confirmability. Credibility was ensured through the engagement of professional nurses as charge sisters (with expertise in the medical and surgical units) in the management situation in their own nursing practices. Consensus between the researcher and the supervisor (co-coder) was reached with regard to the categories derived from the data collected. Furthermore a literature review was conducted and the data analysis brought forward known concepts of management and combating the HIV. To ensure that the findings and interpretations of findings were credible and dependable the supervisor guided the research throughout the process (Lincoln \& Cuba, 1986:317-318,Talbot, 1995:488).

\section{Ethical measures}

Strict ethical measures were adhered to during this research study. These will include the right to privacy, confidentiality and anonymity. The participants will in no way be linked to the research findings. The research will not harm the participants in for example jeopardizing their positions. Par- ticipants were asked to participate in the study (informed consent) and will have the right to express their viewpoints regarding the open questions they have to complete. Access to information was ensured and the participants will have access to the results of the research at the end of the research study (Ethical standards RAU, 2002). The ethical committee of the university as well as the training hospital where the researcher was registered as a student approved the proposal for the research and provided ethical clearance for proceeding with this ethical sensitive issue.

\section{Description of the findings}

For each of the main components/questions of planning, organising, directing and control, the following similar categories emerged, each with their related themes:

$\begin{array}{ll}1 & \text { Situational analysis } \\ 2 & \text { Education } \\ 3 & \text { Taking effective precautions. } \\ 4 & \text { Counselling } \\ 5 & \text { Management of equipment and supplies } \\ 6 & \text { Delegation and supervision } \\ 7 & \text { Recording }\end{array}$

\section{Category 1: Planning}

The first research question was:

"How should the charge sister plan to combat the spreading of the HIV in the health care unit?"

According to Mc Connell, (1997:51) planning is the process of determining what should be done, why it should be done, where it should be done and how it should be done. From the data analysis the planning activities of the unit involve situational analysis, education, taking effective precautions, counselling, management of equipment and supplies, delegation and supervision and recording in the health care unit. Table 1 sets out the subcategories and related themes identified for the category of planning.

The subcategory situational analysis is the analysis of the situation as it occurs in the unit. A nurse must be able to make all relevant observations of the patient in order to plan effectively in the prevention of HIV in the health care unit. From table 1 it is clear that the situation analysis in planning of the daily routine in the unit on prevention of HIV/AIDS does include the staff and patient population.

Education of the patient should be done continuously in the health care unit. According to Muller (1998:340) patient education forms part of the professional responsibilities that are set out in the scope of practice. In order to obtain a maximum effectiveness, educational programmes should take into account the characteristics of the different patients, their knowledge and attitudes, their capacity of understanding, and the forms of communication most likely to be acted upon by the patient. Education can help to alleviate fear dispel ignorance and expose myths about the HIV/AIDS disease.

Planning precautions refers to the charge sister that should 
Table 1 Subcategories and related themes with regard to planning in the nursing unit

\begin{tabular}{|c|c|c|}
\hline Main Category & Planning & \\
\hline Subcategories & Related themes & Examples of quotes to support themes \\
\hline Situation analysis & 1.Assess potential treats & $\begin{array}{l}\text { "The routine daily duties of the ward to be } \\
\text { assessed for their potential in spreading" }\end{array}$ \\
\hline Education & $\begin{array}{l}\text { l.Use various educational } \\
\text { methods } \\
\text { 2.Focus on the HIV/AIDS } \\
\text { condition }\end{array}$ & $\begin{array}{l}\text { Plan to "use audio-visual education" } \\
\text { "Educate the personnel on the HIV/AIDS con- } \\
\text { dition" }\end{array}$ \\
\hline $\begin{array}{l}\text { Taking effective } \\
\text { precautions }\end{array}$ & $\begin{array}{l}\text { 1.Setting invasive proce- } \\
\text { dures in place } \\
\text { 2.Caution patients and visi- } \\
\text { tors }\end{array}$ & $\begin{array}{l}\text { "The personnel should always treat any (all) } \\
\text { invasive procedures with an attitude of spread } \\
\text { prevention" } \\
\text { "Warn pt's and visitors on handling of sharps } \\
\text { that might be lying around" }\end{array}$ \\
\hline Counselling & $\begin{array}{l}\text { 1.Involvement of } \\
\text { stakeholders }\end{array}$ & "Arrange counselling for HIV/AIDS patients" \\
\hline $\begin{array}{l}\text { Management of equip- } \\
\text { ment and supplies }\end{array}$ & $\begin{array}{l}\text { 1.Disposing used supplies } \\
\text { and equipment }\end{array}$ & "Proper disposal of sharps and syringes." \\
\hline $\begin{array}{l}\text { Delegation and super- } \\
\text { vision }\end{array}$ & $\begin{array}{l}\text { 1. Taking into account pre- } \\
\text { vious knowledge } \\
\text { 2.Involvement of staff }\end{array}$ & $\begin{array}{l}\text { "Ensure that everyone has an in depth knowl- } \\
\text { edge about the possible spread mechanism in } \\
\text { the unit." } \\
\text { "Let the staff be actively involved" }\end{array}$ \\
\hline Recording & 1.Install notice board & $\begin{array}{l}\text { "Notices should be put up in all cubicles and } \\
\text { dressing room for not to pick up uncovered } \\
\text { needles or to do so carefully" }\end{array}$ \\
\hline
\end{tabular}

plan how to prevent the spread of HIV in the health care unit. All the safety measures to be followed in the unit should be put in place, e.g. not to re-cap the needles after used. Taking effective precautions in planning to prevent HIV from spreading in the health care unit is supported by the related themes with the quotes from the respondents as indicated in table 1 .

According to Mellish (2001:320), counselling is a personto-person form of communication. Counselling is a service to individuals in need of assistance which will help them to clarify a problem in their own minds, identify the cause of the problem and arrive at a decision as to the best way in which to sole the problem or cope with the situation. For the charge sister to plan effectively in order to offer the service of counselling to the their patients, the charge sister should have a knowledge of counselling. An example of a quote is given in table I to support the theme, namely the involvement of stakeholders that was identified as a sub category of counselling. The charge sister should see counselling as an integral part of all health care programmes and activities for prevention and control of HIV from spreading in the health care unit. There is a need for the charge sister to plan counselling, as HIV/ AIDS became a pandemic in S.A, therefore, the charge sister should be able to plan for counselling of the patient to prevent the spreading of HIV. It is evidence by the quotes above that the staff should be involved in counselling of the patient.

\section{Management of equipment and supplies in plan- ning to combat the spreading of HIV in the health care unit should be done with the use of cor- rect unit policy on handling of con- taminated articles in the unit. Dis- posal should be properly done in the correct manner on a daily basis. From the data it be-} came apparent that the charge sister should plan to manage and handled contaminated items such as sharps, syringes, linen and waste correctly in the health care unit in a daily basis to prevent the spread of HIV. It is important that health care providers have sufficient supplies and equipment, especially when invasive procedures are involved or when risk of significant exposure to blood and other body fluids is likely (Nurses day, 2003:44).

The sixth sub category identified was related to delegation and supervision.

According to Muller (1998:174), delegation refers to the devolution of duties, task and responsibilities by a supervisor to a subordinate in the nursing unit. The principles and process of delegation requires the assessment of the work, assessment of the subordinate's abilities, delegation of the work as well as professional liability. The charge sister should plan accordingly to ensure that staff in the unit executes their delegated task without being at risk of contracting and spreading the HIV in the unit. The two themes of previous knowledge and involvement of staff were identified as important. The involvement of the staff 
during delegation will promote good working condition. Good working condition may improve the staff willingness to prevent the spread of HIV in the health care unit.

The sub category of recording was analysed. The use of notices in the health care unit has to be planned by the charge sister in order to offer a continuous education. It was an indication of the fact that the method of education is utilised in the form of record as evidenced by the quotes above.

From the above discussion it was clear that the component of planning is executed in prevention of the spreading of HIV/AIDS in the health unit. The conclusions drawn from the data analysis of the category planning were that; the daily routine of the health care unit should be assessed for its potential in spreading HIV. (Theme: Situational analysis) it is necessary to educate staff on the HIV/AIDS condition and the various possible modes of spreading of the virus and with the use of appropriate educational methods. (Theme: Education) applicable and warning signs and verbal warning should be utilised to both staff and patient to take effective precautionary measures to prevent unnecessary spreading of HIV in the health care unit. (Theme: Taking effective precautions) relevant stake holders should be involve in rendering the service of counselling to the patient. (Theme: Counselling)

the nursing unit should have an adequate plan to properly dispose contaminated supplies and equipment. (Theme: Management of equipment and supplies) the supervisor should plan effectively on how and when to delegate and supervise staff members and taking into account their previous knowledge to ensure that the preventative measures to prevent spreading of HIV during the execution of the daily unit activities. (Theme: Delegation and supervision) the use of notices should be installed in the unit to offer continuous education. (Theme: Recording)

\section{Category 2: Organising}

The second research question stated:

"How should the charge sister organize the daily nursing activities in the unit to prevent the spreading of the HIV in the health care unit?" Therefore, organising relates to the second main category.

According to Roos (2001:118), organization in the nursing unit refers to the orderly structuring of functions or responsibilities in order to realize a common objective. It requires job division by way of an organizational, the demarcation of authority in the form of line and staff functions, as 
well as the delegation of duties, tasks and responsibilities to the appropriate members.

The following sub categories and themes were identified for the category of organizing (Table 2 ):

The subcategory situational analysis revealed the theme related to ensure availability of resources. The related quote in table I states that the charge sister must make sure that he/she organise resources such as gloves, sharps container and etc available to comply with the universal precautionary measures in the health care unit to prevent the spreading of HIV in the health care unit.

The sub category education support the theme uses various education methods. The utilisation of the self-explanatory methods in the educating the patients, public and the staff in the health care unit should be the ultimate responsibility of the charge sister to organise it, as it helps to offer a continuous education to everyone in the unit. Informal staff gatherings/discussions to share experiences in living and working with HIV/AIDS should be facilitated (Nurses day, 20(3):44). Effective AIDS educational programmes make information eadily available to employees. A variety of educational approaches (newsletters, brochures, videos etc.) should be used to reach every employee, and to change behaviour (Kohl \& Miller, 1994: 48).

Taking effective precautions is another sub category and various quotes from the respondents supported the theme of use of universal precaution. The charge sister has the duty to ensure that the universal precautionary measures are used in the unit by planning its use to prevent the spread of HIV in the health care unit as supported by the above quotes.

The sub category counselling has the theme on assessing individual needs.

The patient's needs should be assessed in order to offer the patient with the required services such proper referrals and to inform the counsellor. It is the duty of the charge sister to make sure that the patient's needs are met.

One theme was identified for the sub category management of equipment and supplies, namely using and disposing contaminated items. A quote from a respondent is provided in table 2 . The charge sister has the responsibility to ensure that the unit activities is organise to prevent the spread of HIV in the unit during the execution of the daily routine such as separating contaminated linen from dirty clean linen, cleaning of patient beds on discharge of the patient, correct disposal and handling of contaminated items as indicated in the quotes above.

In the sub category of delegation and supervision it was identified that the theme on acknowledging the skills and knowledge was important. One respondent stated the "tasks should be delegated to staff according to level of competence; putting of intravenous lines. A person who knows or has be exposed to the procedure. Knowing how to put up a drip without any risk of pricking himself or causing unnecessary spillage of blood all over the show". The charge sister has the professional obligation to ensure that the delegated task is according to the staff level of knowledge and skills as lay down on the scope of practice as set by the SANC to prevent the spreading of HIV in the health care unit during the execution of the delegated task.

In the sub category recording, the following quote supported the theme, of keeping statistics: "To have daily statistics for the HIV patient". The quote indicates that the charge sister should ensure that there daily statistic of the HIV positive patient in order to organise the activities of the unit effectively on the preventative measures to be utilised in the health care unit to prevent the spreading of the virus. According to Mellish (2001:171), accurate record keeping form the basis for reassessment, re-planning, re-implementation and re-evaluation for the present and the future.

From the above discussion it is apparent that the component of organising the prevention of spreading of HIV is a crucial step. The conclusions drawn from the data analysis of the category organization were that;

the effective ordering and availability of supplies and equipment according to the situation in the unit can influence the effective management of the spreading of the virus. (Situation analysis) various educational methods should be in place so that staff members and patients can visualise the spreading of the disease. (Education) universal guidelines should be available for all staff members to follow the same steps and procedures, in establishing an effective routine, in combating the spreading of the virus. (Taking effective precautions)

an effective counselling process should be in place to refer staff members and patients when needed. (Counselling)

the daily routine of the unit should include the using and effective disposing of contaminated linen. (Management of equipment and supplies) the charge sister should delegate responsibilities and tasks to nurses, according to their knowledge, skills and scope of practice. (Delegation and supervision)

the charge sister should encourage staff members to keep record of all tasks performed to the patient, according to which she can hand in complete statistics of the patients in her unit. (Recording)

\section{Category: Directing}

The third research question stated:

"How should the sister direct the nursing staff to effectively prevent the spreading of the HIV in the unit environment?" Therefore, directing is the third main category.

Directing refers to the unit manager's leadership responsibility, namely to give direction and ensure that goals are achieved in the unit. The unit manager should also facilitate harmony in the nursing unit and focus on the principles of teamwork in the health care unit (Dienemann, 1998:163). Generally, the prevention of the spreading of HIV in the health care unit may be achieved by the use of the 


\section{Table 3 Subcategories and related themes with regard to directing in the nursing unit}

\begin{tabular}{|c|c|c|}
\hline Main Category & Directing & \\
\hline Subcategories & Related themes & Examples of quotes to support themes \\
\hline Situation analysis & $\begin{array}{l}\text { 1.Encouragement of staff } \\
\text { participation } \\
\text { 2.Maintain nursing stand- } \\
\text { ard }\end{array}$ & $\begin{array}{l}\text { "Encourage the staff to be fully participating } \\
\text { in prevention of the spread" } \\
\text { "Not to touch the next patient with the same } \\
\text { gloves" }\end{array}$ \\
\hline Education & $\begin{array}{l}\text { 1.Use various educational } \\
\text { programmes and methods }\end{array}$ & $\begin{array}{l}\text { "Give in-service about the universal precau- } \\
\text { tions" }\end{array}$ \\
\hline $\begin{array}{l}\text { Taking effective } \\
\text { precautions }\end{array}$ & $\begin{array}{l}\text { 1.Correct handling and dis- } \\
\text { posal of sharps }\end{array}$ & $\begin{array}{l}\text { "Precautions should be taken when dealing } \\
\text { with HIV/AIDS patients" }\end{array}$ \\
\hline Counselling & 1.Follow protocol & $\begin{array}{l}\text { "Ensure that everyone knows, ... the proto- } \\
\text { col to follow in case of a needle prick" }\end{array}$ \\
\hline $\begin{array}{l}\text { Management of equip- } \\
\text { ment and supplies }\end{array}$ & $\begin{array}{l}\text { 1.Using and disposal of } \\
\text { contaminated items }\end{array}$ & $\begin{array}{l}\text { "Floors to be cleaned with disinfected solu- } \\
\text { tion, beds and bedside locker" }\end{array}$ \\
\hline $\begin{array}{l}\text { Delegation and super- } \\
\text { vision }\end{array}$ & $\begin{array}{l}\text { 1.Effective utilisation of in- } \\
\text { fection control policy } \\
\text { 2.Retaining knowledge and } \\
\text { taking responsibility }\end{array}$ & $\begin{array}{l}\text { "Supervise and encourage staff, (Nurses) to } \\
\text { follow the infection control policy" } \\
\text { "They should internalise the precautionary } \\
\text { measures, it should always ultimately be each } \\
\text { individual's responsibility to make sure that } \\
\text { HIV/AIDS is prevented from spreading in the } \\
\text { unit" }\end{array}$ \\
\hline Recording & 1.Placing notices & $\begin{array}{l}\text { "Notices should be put up not to pick up used } \\
\text { and uncovered needles or rather to pick them } \\
\text { up without touching the steel part" }\end{array}$ \\
\hline
\end{tabular}

correct managerial skills and the quality of the resources available to be utilized in the unit. The charge sister should be able to organize the day-to-day activities effectively in the unit. Charge sister should also be knowledgeable with regards to the management of HIV/AIDS. (McConnell, 1997:52)

The following subcategory and themes were identified for the category of directing.

In the sub category related to situational analysis the theme encouragement of the staff participation, emerged. In directing the staff, the charge sister has to analyze he ward situation, and encourage the staff to participate in prevention of HIV- virus from spreading in the health care unit during their execution of their duties.

The theme maintaining nursing standards is outlined in table 3. One participant stated the following: "Proper nursing care of the HIV patient should exist through using pre- ventive measures e.g. wearing gloves when handling the patient, and removed them after handling the patient". The charge sister must ensure that the nursing standards in the health care unit is of high quality and regarding the prevention of HIV from spreading and the charge sister should direct the activities of the unit to prevent the spread of the virus.

The sub category named education has the theme of using various educational programme and meth$o d s$. Two of the quotes were;

"Give health education about the mode of spread of the disease to the patient"; and "Educating all personnel in unit to take universal precautionary measures with every patient". Results of previous research have revealed that nurses are aware of the main routes through which HIV can be transmitted but still sometimes uncertain regarding the possibility of contracting HIV through being coughed or sneezed on (Lim \& Loo, 2000: 132).

The charge sister should direct the educational programme as planned to ensure that the staff and the patient are educated on different topics such as the universal precaution. mode of spread of HIV to empower them to able to prevent the spreading of the HIV in the health care unit. Continuous education to the learner should the responsibility of the charge sister to organise and direct the running of the programmes. The above quotes indicate that there is a need for education on the precautionary measures to the learners. This will empower the learners with the knowledge in order to prevent the spreading of HIV in the health care unit. All staff should be trained in patient's rights and the right to equal care and confidentiality (Nurses day, 2003:45).

Only one theme was identified relating to taking effective precaution, namely correct handling and disposal of sharps. Several quotes were made of which an important 
one is "Adherence to the golden rule of one needle per patient and syringe usage." The role of charge sister during directing the activities of the unit during the execution of the task to prevent the spread of the HIV involve the taking of effective precautionary measures by the staff as evidence by the quotes above.

Counselling is playing a more prominent role in current health services. The theme of follow protocol" was identified through a quote; "Ensure that everyone knows, ... the protocol to follow in case of a needle prick".

The charge sister should ensure that the protocol for needle stick injury is followed at all times. The injured person should e.g. to be referred to a counsellor to debrief the situation.

Management of equipment and supplies as a sub category, included the theme of using and disposal of contaminated items. The charge sister should direct the staff to dispose sharps, waste products correctly as evidence by the above quotes. Charge sister should direct the staff in the unit to use sharp container, red bags, disinfectant agent and the gloves to manage the contaminated items. The staff should be directed on proper management of contaminated item and the use of preventative measures during the rendering of the service.

The theme, effective utilisation of infection control policy, was highlighted in the sub category of delegation and supervision. The charge sister should supervise and organise the staff in the unit to follow the infection control policy to prevent the spread of HIV in the unit. Supervision should be don by the charge sister at regular interval to ensure that the policy is followed at all times. Another theme was identified, namely retaining knowledge and taking responsibility. The charge sister should make sure that the staff in the health care unit retain the knowledge of the precautionary measures and should take responsibility to ensure that the HIV is prevented from spreading in the unit as supported by the quotes.

In the sub category, recording, the quote emphasised the importance of recording important information in the theme, placing notices. The use of notices will help the charge sister in directing the activities of the unit as it was in a written form to make the public, patient and the staff aware of the correct methods of dealing with e.g. used needles in the health care unit.

From the above discussion it became clear how important the role of the directing component is in combating the spreading of HIV in the health care unit. The conclusions drawn from the data analysis of the category directing were that;

staff should be encouraged to participate in the prevention of HIV from spreading in the unit.

(Situational analysis)

the running of the different educational programme should be directed to make sure that the appropriate educational methods are utilised to educate both staff and patient about the mode of spreading of
HIV and the precautionary measures in the unit. (Education)

activities of the unit should be directed towards prevention of spreading the HIV during execution of the task using the correct handling and disposal of sharps. (Taking effective precautions)

it should be ensured that the needle stick injury protocol is in place in the unit and to be followed at all times. (Counselling)

staff members are guided on proper management of contaminated items such as correct handling of was product and correct disposal of sharps to prevent spread of HIV in the health care unit. (Management of equipment and supplies)

staff should be supervised and organised in the unit to follow the infection control policy to prevent the spread of HIV in the unit. (Delegation and supervision)

staff and patient should be aware of the importance of the notices placed in the unit for the prevention of HIV. (Recording)

\section{Category: Control}

The fourth research question was:

"On which control measures should the charge sister focus to combat the spreading of the HIV in the health care unit?" Controlling was thus the fourth main category.

Controlling is the follow up and correction of activities, supervision looking at actions and making adjustments to encourage outcomes to conform with expected or required results (McConnell, 1997:52).

Table 4 outlines the subcategories and themes of the category control:

Three themes were identified for the sub category situational analysis.

The theme on previous knowledge had one quote that suggested that the charge sister should assess the previous knowledge of the staff in order to plan the control measures to prevent HIV from spreading in the health care unit. The second theme was, control material resources and the relevant quote highlighted that to control the spread of HIV in the health care unit, the charge sister should ensure that there are sufficient supplies of material as evidenced by the quote. The third theme addressed the regular application of precautionary measures to control the spread of HIV in the unit that should be done regularly in the unit.

Education of the patient should be done continuously in the health care unit. Several quotes supported the theme of professional development and highlighted the importance of continuous staff development including various speakers, attending outside conference and focusing on the current behaviour of patients. Kohl and Miller ( 1994:47) point out that organisations must provide their employees with comprehensive training programmes in order to reduce risky behaviours which spread HIV and to change biased attitudes which may lead to moral and legal problems.

The subcategory of taking precautions outlined the themes 


\begin{tabular}{|l|l|l|}
\hline Main Category & Related themes & Examples of quotes to support themes \\
\hline Subcategories & $\begin{array}{l}\text { 1.Acknowledge previous } \\
\text { knowledge } \\
\text { 2.Control material re- } \\
\text { sources } \\
\text { 3.Regular application of } \\
\text { precautionary measures }\end{array}$ & $\begin{array}{l}\text {-"She should ensure that every staff member } \\
\text { in her unit is well educated re HIV/AIDS" } \\
\text {-"Efficient supply (readily available) of mate- } \\
\text { rials (gloves, sharps, bins etc)" } \\
\text {-"Universal precautionary measures to be } \\
\text { applied at all times" }\end{array}$ \\
\hline Education & $\begin{array}{l}\text { 1.Professional develop- } \\
\text { ment }\end{array}$ & $\begin{array}{l}\text { "Have different members of staff give talks in } \\
\text { the topic to ensure that everyone knows what } \\
\text { this is all about" }\end{array}$ \\
\hline Taking effective \\
precautions & $\begin{array}{l}\text { 1.Use of aseptic technique } \\
\text { 2.Usage and disposal of } \\
\text { sharps }\end{array}$ & $\begin{array}{l}\text { "By applying aseptic techniques when doing } \\
\text { procedures" } \\
\text { "They should be aware of the correct disposal } \\
\text { of sharps and the precautions when handling } \\
\text { sharps e.g. never recapping/ needles etc" }\end{array}$ \\
\hline Recording & 1.Empowerment of patient & $\begin{array}{l}\text { "Education of patients re: spread of HIV/ } \\
\text { AIDS" and "precautions that should be taken } \\
\text { and living with the disease" }\end{array}$ \\
\hline $\begin{array}{l}\text { Management of equip- } \\
\text { ment and supplies }\end{array}$ & $\begin{array}{l}\text { 1.Proper management of } \\
\text { body fluids }\end{array}$ & $\begin{array}{l}\text { "The correct methods of handling of body } \\
\text { fluids and the disposal thereof." }\end{array}$ \\
\hline vision & 1.Regular observation & $\begin{array}{l}\text { "Spot-checks of staff while they perform their } \\
\text { duties in the unit" }\end{array}$ \\
\hline and super- & $\begin{array}{l}\text { "Notices reminding (teaching) measures to be } \\
\text { taken in prevention of spread" }\end{array}$ \\
\hline
\end{tabular}

their present situation and this required the charge sister to plan the educational programme to follow. Relevant human resources issues that should be addressed in the organisational policy include health insurance, healthcare costs, job accommodations, work disruptions, discrimination and harassment of HIVinfected workers, decline in productivity and workplace morale (Lim \& Loo, 2000: 132).

In the category of management of equipment and supplies, the theme, propermanagement of body fluids was confirmed by a quote stating, “...blood spills be treated with

of usage of aseptic technique and usage and disposal of sharps. The charge sister should ensure that the staff does use the aseptic technique to prevent unnecessary spreading of HIV in the unit in order to control the spread. Furthermore the charge sister should ensure that all the staff carries out the effective precautionary measures during their execution of their duties as supported by the quotes. The organisational AIDS policy should state explicitly how the organisation and units should treat existing and potential employees who become or are already infected with HIV (Lim \& LoO, 20(0): 132).

Counselling as a subcategory focused on the role of the charge sister to exercise control in maintaining counselling sessions where needed, to empower patients to live with the disease. The theme of, empowerment of patients came to the fore in one quotation (Table 4). The education of patients is the responsibility of the charge sister during the patient's period of hospitalisation to empower them with the knowledge and to make them to come into terms with bleach before wiped up". In order to control the spread of HIV in the health care unit, the charge sister should ensure that the correct handling of body fluids is carried out as evidenced by the above quotes.

The sub category titled delegation and supervision, firstly enlightened the theme on regular observation. One quote stated: "Have regular checks to the see if all sharps containers are properly closed and are not overflowing." Another respondent stated: "Have direct supervision of staff." Supervision should be done regularly and unstructured in the health care unit to promote the use of preventative measures by the staff. The charge sister has the responsibility to delegate the task to the staff and to make sure that the regular checking is done to ensure that the delegated task is carried out without any risk of spreading the HIV. An achievement checklist could also be used $s$ a self-assessment tool for managers in assessing how well their ward/ unit reaches, serves and treats HIV-positive patients (Nurses day, 2003:45). 
The manager should check that adequate record keeping (category in table 4) in the form of e.g. notices, make staff and patients aware of how to prevent spreading of the HIV. The theme "Install notices" highlight the above. The quote "Notices reminding (teaching) measures to be taken in prevention of spread" was made. The charge sister should write notices and utilise it to remind the staff, patient and the public on the preventative measures in the form of records in the health care unit. On the other hand, policies should clearly outline how the organisation intends to deal with employee and patient confidentiality and privacy (Lim \& Loo, 2()(): :132).

From the above it is clear how important the managerial component of control is in managing the prevention of the spreading of HIV in the health care unit. According to Muller (1998:134-135), control is not a bureaucratic action, but rather the empowerment of subordinates or group members to achieve the set objectives successfully. Continuous control refers to supervising and directing in the unit - supervising and directing which focus on the empowerment of personnel in the unit to provide quality nursing care (McConnell, 1997:52)

The charge sister should use all her managerial functions to prevent the spreading of HIV among staff and patients in the health care unit. The conclusions drawn from the data analysis of the category control were that;

continuous assessment of staff knowledge is needed on the preventative measures to prevent the spread of HIV and reinforcement of the previous knowledge on the importance of regular application of precautionary measures to prevent the spreading of HIV in the health care unit. (Situational analysis) continuous staff development should be encouraged by utilising various educational methods to develop the staff professionally on disease process to empower them with knowledge to prevent the unnecessary spreading of HIV in spreading due to lack of knowledge. (Education)

it should be ensured that the correct disposal of sharps and precautions when handling the sharps are carried out by all staff with the use of regular observation of the staff during execution of their task in the unit. (Taking effective precautions) continuous education of patients is needed on the mode of spread of HIV to empower them with the knowledge. (Counselling)

controlling the spread of HIV is essential in the unit by making sure that the correct management of body fluids are carried out during execution of daily unit activities by the staff. (Management of equipment and supplies)

regular and unstructured observation should be done in the unit to promote the use of preventative measures by the staff during execution of the daily unit activities. (Delegation and supervision) notices should be installed in the unit to remind the staff, patients and the public on the preventative measures on the prevention of the spreading of HIV from spreading. (Recording)

\section{Recommendations}

\section{General}

The employer of the health care personnel should ensure that policies exist for the following:

- Initial orientation and continuing education and training of all health care workers, including the students on the epidemiology, modes of transmission, and prevention of HIV

- Provision of adequate equipment and supplies necessary to minimise the risk of HIV infection.

Monitoring adherence to recommended protective measures. When monitoring reveals a failure to follow recommended precautions, therefore counseling, education and or re-training should be provided and if necessary the appropriate disciplinary action should be considered.

From the data analysis various recommendations were made that could be the departure of a policy statement on the prevention of the spreading of HIV in the health care unit.

The charge sister should pay attention to the following guidelines on the component of planning that address her/ his role in the combating of spreading of the HIV virus:

Avoid cross-infection e.g. using clean needles syringes for each patient. Adequate supplies should be available on a daily basis.

Plan ahead, staff should use gloves when handling HIV positive patients especially when a patient has a laceration or open wound.

Plan to educate the staff and patients in the unit plus the community on HIV and AIDS on every detail, how to prevent it's spreading. Work out a plan of action for each unit to conform to this ideal situation.

Accept the responsibility of planning the correct handling of equipments used for the HIV positive patients e.g. a bone marrow procedure.

Assess the daily routine of the health care unit for its potential in spreading the HIV.

Schedule a regular in-service training for the staff in the health care unit.

Plan to use appropriate educational methods and AIDS in educating the staff and the patients in the health care unit.

Educate the staff on the HIV/AIDS condition and the various modes of spreading of the virus, and precautionary measures.

Plan to use a staff rotational system to encourage staff members to attend the HIV course provided by the nursing service.

Encourage staff to plan to use precautionary measures all the times when performing any procedure that involve body fluid of patients.

Involve relevant available stakeholders in providing counselling both to patients and the staff members. 
Have an adequate plan to properly dispose contaminated supplies and equipment.

The charge sister should pay attention to the following guidelines on the component of organizing that address her/his role in the combating of spreading of the HIV:

Organise in-service training sessions for nursing staff and other health care workers e.g. ward helpers on the prevention of spreading of HIV /AIDS. Encourage nursing staff to arrange their trolleys in such a way that all items needed to prevent the spreading of infection of any kind, is in the trolley such as gloves and sharp container to discard used needles.

Remind them on a daily basis of the measures to be taken to prevent oneself of obtaining the virus, because anything can happen to the nursing staff e.g. needle pricks.

Encourage hand washing as a must, that is part of the daily routine, done thoroughly and encourage staff to do it as often as possible, e.g. between patients.

Ensure effective organisation of ward activities, by ensuring that there are adequate equipment e.g. gloves and sharps containers. They should be utilised during the execution of the health care unit activities to comply with the universal precautionary measures.

Organise self-explanatory visual AIDS. For example posters should be displayed in the health care unit to warn the patient, staff and the public on the possible mode of spreading e.g. needle pricks and human fluids.

Formulate a protocol to be followed in the event of needles stick injury in the care unit and make it available in the unit.

Organise the staff to follow the universal precautionary measures e.g. wash hands after handling each patient. handling of specimen as high risk for spreading of the HIV in the unit, wear gloves all the times when working with contaminated articles and body fluids, do not re-cap the needle after usage and etc.

Organise counselling for the patient or staff member who needs counselling. The charge sister for immediate referrals should know the times and counselling hours.

The charge sister should pay attention to the following guidelines on the component of directing that address her/ his role in the combating of spreading of the HIV:

Guide staff in the use of facilities or equipment, to prevent spread of HIV/AIDS at all times.

Ensure that all the blood components i.e. blood platelets are thoroughly checked and HIV free. Act as a role model in taking precautionary measures like discarding sharps i.e. needles, into proper sharps containers and to always use gloves as stipulation by the infection control policy of the service.

The charge sister should pay attention to the following guidelines on the component of control that address her/ his role in the combating of spreading of the HIV:

Observe that nursing staff doesn't have cuts on their skin, for in case they come into contact with infected blood products. Staff should be notified to close all cuts using Elastoplasts and to wear gloves. Ensure that the staff member properly follow the procedure of disposal of needles into the sharps container. The charge sister should check this during her daily ward rounds.

Have ward discussions and ask staff member's questions on the prevention of spreading of HIV/AIDS. She should be certain that each staff members are aware of the patient conditions so as to take special precautions.

\section{Conclusion}

A policy could be used by nursing staff in combating the spreading of the HIV in a health care service. This should direct the future nursing activities of the health care unit and was used during in-service training sessions in educating all the nursing staff of the guidelines. All charge sisters should through to planning, organising, directing and control, prevent the spreading of HIV in the health care unit.

\section{Bibliography}

BABBIE, E \& MOUTON, J 2001: The practice of social research. South African edition. Cape Town: Oxford.

BRINK, HIL 2001: The fundamentals of research methodology for health care professional. Durban: Butterworths.

BURNS, N \& GROVE, SK 1987: The practice in research. Philadelphia: Saunders.

BURNS, N \& GROVE, SK 1993: The practice in nursing research; conducts, critique and utilization. $2^{\text {nd }}$ Edition. Philadelphia: Saunders.

CRESSWELL, JW 1994: Research design: Qualitative and quantitative approaches. California: Sage.

DAFT, RL 1999: Leadership. Theory and practice. London: Harcourt College.

DEMOCRATIC NURSING ASSOCIATION OF SOUTH AFRICA 1998: Ethical standards of nurse researchers. Pretoria: DENOSA.

DIENEMANN, JA 1998: Nursing administration. Managing patient care. $2^{\text {nd }}$ edition. Stamford: Appleton \& Lange.

JOOSTE, K 2001: Leadership in Introduction to health services management. Edited by Booyens SW. Kenwyn: Juta.

KOHL, JP \& MILLER, AN 1994: US organizations' response to AIDS in the workplace: A review and sugges- 
tions for managers. Management decision. 32(4): 43-5I.

KREFTING, L 1991: Rigor in qualitative research: The assessment of trustworthiness. The American Journal of Occupational Therapv. 45(3): 214-222.

LIM, FKG \& LOO, GL 20M): HIV and the workplace. International Journal of manpower. 21(2):129-140.

LINCOLN, YS \& GUBA, EG 1985: Naturalistic enquiry. Beverly Hills: Sage.

MAXWELL, JA 1996: Qualitative research design. An interactive approach. London: Sage.

McCONNEL, CR 1997: The effective health care supervisor. $4^{\text {th }}$ Edition. New York: Aspen.

MELLISH, JM, BRINK, HIL \& PATON, F 1998: Teaching and learning: The practice of Nursing. $2^{\text {nd }}$ Edition. Sandton: Heineman.

MULLER, M 1998: Nursing Dynamics. $2^{\text {nd }}$ Edition. Sandton: Heineman.

NURSES DAY (EDITORIAL) 2003: International nurses day 2003. Nurses: Fighting AIDS Stigma; caring for all. Nursing update. $27(2): 38-47$.

RAND AFRIKAANS UNIVERSITY.FACULTY OF EDUCATION AND NURSING 2002: Ethical standards. Aucklandpark: RAU.

ROOS, J 2001: Organization in the health services in Introduction to health services management. Edited by Booyens SW. Kenwyn:Juta.

TALBOT, LA 1995: Principles and practice of nursing research. London: Mosby.

WOODS, NF \& CATANZARO, M 1988: Nursing Research: Theory and Practice. Toronto: Mosby.

http://journalism.berkeley.edu/projects/safrica/adapting/ rape.html

http://www.infoweb.org/library/misc/misc000040.html 